\title{
Analisis Daerah Rawan Kecelakaan Lalu Lintas pada Ruas Jalan Tol Surabaya-Gempol
}

\author{
Asep Fahza dan Hera Widyastuti \\ Departemen Teknik Sipil, Fakultas Teknik Sipil, Lingkungan, dan Kebumian \\ Institut Teknologi Sepuluh Nopember \\ E-mail: hera@ce.its.ac.id
}

\begin{abstract}
Abstrak-Kecelakaan lalu lintas merupakan indikator utama tingkat keselamatan jalan raya. Di negara maju masalah keselamatan jalan merupakan masalah yang sangat diperhatikan guna mereduksi kuantitas kecelakaan yang terjadi. Hal ini menjadi indikator terhadap pentingnya memahami karakteristik kecelakaan. Jumlah korban yang cukup besar akan memberikan dampak ekonomi (kerugian material) dan sosial yang tidak sedikit.

Tujuan tugas akhir ini adalah menghitung besarnya angka kecelakaan pada ruas jalan tol Surabaya-Gempol, menghitung nilai ekonomi akibat kecelakaan berdasarkan tingkat keparahan korban menggunakan metode The Gross Output (Human Capital). Menganalisis daerah rawan kecelakaan (Balck Site) dengan metode Z-Score dan Cummulative Summary (Cusum), membuat titik daerah rawan kecelakaan pada ruas jalan yang sering terjadi kecelakaan. Dari hasil analisis menunjukkan bahwa ruas jalan yang memiliki Accident Rate tertinggi untuk korban meninggal dunia dunia di jalan tol Surbaya-Gempol adalah pada tahun 2016, untuk luka berat pada tahun 2016, untuk korban luka ringan adalah pada tahun 2014. Uji Hipotesis One Way-ANNOVA membuktikan bahwa bulan dan harinya terjadinya kecelakaan lalu lintas memberikan hasil yang sama identik, tidak berpengaruh terhadap kejadian kecelakaan, sedangakn jam terjadi, jenis kelamin dan cuaca kejadian kecelakaan memberikan hasil sebaliknya yaitu berbeda nyata atau berpengaruh pada terjadnya kecelakaan. Dari hasil perhitungan menggunakan metode The Gross Output (Human Capital) didapat nilai ekonomi akibat kecelakaan lalu-lintas yang melibatkan korban meninggal dunia (tahun 2012-2016) sebesar Rp. 14.931.019.884,70, sedangkan korban luka berat (tahun 20122016) sebesar Rp. 2.711.662.398,14, dan korban luka ringan (tahun 2012-2016) sebesar Rp. 1.338.232.607,76. Dengan metode Z-Score diperoleh daerah rawan kecelakaan pada ruas jalan tol Waru-Sidoarjo pada STA 24-25. Lokasi Black spot terletak di STA 18-19 dan STA 22-24.
\end{abstract}

Kata Kunci-Jalan Tol, Black Spot, Collision Diagram, Kecelakaan Lalu lintas, One Way-ANOVA, The Gross Output.

\section{PENDAHULUAN}

$\mathrm{K}$ ECELAKAAN lalu lintas merupakan salah satu penyebab kematian terbesar di Indonesia. Jumlah korban yang cukup besar akan memberikan dampak ekonomi (kerugian material) dan sosial yang tidak sedikit, berbagai usaha prefentif hingga perbaikan lalu lintas dengan melibatkan berbagai pihak yang terkait hasilnya belum sesuai yang diharapkan.

Dalam meningkatkan keamanan lalu lintas di jalan terdapat 3 (tiga) bagian yang saling berhubungan dengan operasi lalu lintas, yakni: pengemudi, kendaraan, dan jalan raya. Data kecelakaan yang ada dari Jasa Marga dari tahun ke tahun bahwa penyebab kecelakaan yang terbesar disebabkan oleh faktor manusia (pengemudi). Penyebab kecelakaan yang dilakukan akibat kendaraan terutama jalan raya (geometrik) sangatlah kecil pengaruhnya. Hal ini sangat kontradiksi dengan kenyataan yang ada bahwasanya traffic engineer hanya dapat mengendalikan salah satu bagian, yakni; Jalan Raya.

Jalan tol sebagai jalan bebas hambatan memberikan perbedaan yang nyata dengan jalan biasa. Perbedaan ini diharapkan mampu memberikan kualitas yang lebih mengingat tingkat mobilitas masyarakat yang semakin meningkat. Namun dengan statusnya yang bebas hambatan bukan berarti masalah kecelakaan lalu lintas juga dapat teratasi. Dengan kelebihan-kelebihan yang dimiliki terkadang justru membuat para pengemudi lengah dan beresiko membahayakan keselamatan dirinya dan orang lain. Oleh karena itu diperlukan berbagai upaya untuk meminimalkan kemungkinan terjadi kecelakaan.

Tol Surabaya-Gempol dengan panjang jalan 43 kilometer, jalan tol ini beroperasi secara penuh sejak tahun 1986. Namun dengan bencana lumpur panas Lapindo Brantas Inc, jalan ini terpotong sekitar enam kilometer yang menghubungkan Porong dan Gempol. Pemerintah memutuskan menutup ruas tersebut sebagai jalan tol, sehingga panjangnya berkurang menjadi 37 kilometer. Jalan yang dikelola oleh cabang Surabaya-Gempol ini memiliki 2 x 3 lajur (Waru-Dupak) dan 2 x 2 lajur (Waru-Gempol), tujuh interchange, 27 jembatan perlintasan kendaraan, dan dua jembatan penyeberangan orang. Pada ruas ini terdapat 10 gerbang tol yang terdiri dari enam gerbang tol dengan sistem transaksi terbuka dan empat gerbang dengan sistem transaksi tertutup.

\section{TINJAUAN PUSTAKA}

Tinjauan yang digunakan terdiri atas kajian pustaka serta kajian teori terkait kasus dalam penelitian yang bertujuan agar dapat menyelesaikan masalah yang ada dalam penelitian.

\section{A. Teknik Analisis Data Kecelakaan}

Penarikan kesimpulan pada statistik deskripsi hanya ditunjukkan pada kumpulan data yang ada. Berdasarkan ruang lingkup,biasanya statistik deskripsi meliputi:

1) Distribusi Frekuensi

Distribusi frekuensi adalah data acak dari suatu penelitian yang disusun menurut kelas-kelas interval tertentu atau menurut kategori tertentu dalam sebuah daftar. Distribusi frekuensi terdiri dari grafik disktribusi, ukuran nilai pusat dan ukuran dispersi.

Ukuran Nilai Pusat

Ukuran nilai pusat yang meliputi rata-rata, median, modus, kwartil dan lain sebagainya. Dalam perhitungan pertumbuhan 
indeks kecelakaan ankan mencari nilai raa-rata dengan rumus umum:

$$
\mathrm{X}=\frac{\Sigma \mathrm{xi}}{\mathrm{n}}
$$

Dimana:

$\mathrm{X}=$ Nilai rata-rata

$\mathrm{Xi}=$ Jumlah data

$\mathrm{n} \quad=$ Jumlah sampel

Standar Deviasi

Standar deviasi adalah ukuran yang menyatakan seberapa jauh simpangan nilai-nilaidatadan nilai-nilai pusatnya. Standar deviasi adalah akar dari tengah kuadrat simpangan dari nilai tengah. Simpangan baku (standar deviasi) untuk seperangkat data X1, X2, X3,......Xn (Data tunggal) dapat ditentukan dengan metode biasa, yaitu:

Ukuran Sampel Besar $(n \geq 30)$

$$
\mathrm{S}=\sqrt{\frac{\Sigma(\mathrm{x}-\mathrm{x})}{\mathrm{n}}}
$$

Ukuran Sampel Kecil

$$
S=\sqrt{\frac{\Sigma(\mathrm{x}-\mathrm{x})}{\mathrm{n}-1}}
$$

2) Z-Score

Z-Score adalah bilangan "z" atau bilangan standar atau bilangan baku. Bilangan " $z$ " dicari dari sampel yang berukuran $n$, dengan data-data $\mathrm{X} 1, \mathrm{X} 2, \mathrm{X} 3, \ldots \ldots . \mathrm{Xn}$ dengan rata-rata $X$ pada simpangan baku " $S$ ", sehingga dapat dibentukdata baru yaitu $\mathrm{z} 1, \mathrm{z} 2, \mathrm{z} 3, \ldots \ldots . \mathrm{zn}$ dengan rata-rata 0 simpangan baku 1. Dengan kata lain, nilai z dapat dikatakan seberapa standar deviasi jauh jarak nilai suatu data dengan nilai meannya.

Nilai " $z$ " dapat dicari dengan rumus[1]:

$$
\mathrm{Z}=\frac{\mathrm{X} 1-\mathrm{X}}{\mathrm{s}}
$$

Dimana :

Z1 = Nilai z-score kecelakaan pada lokasi "1"

$\mathrm{S}=$ Standar Deviasi

$\mathrm{Xi}=$ Jumlah data pada lokasi "i"

$\mathrm{X}=$ Nilai rata-rata

$\mathrm{I}=1,2,3,4 \ldots \ldots . \mathrm{n}$

3) Cusum (Cummulative Summary)

Cusum (Cummulative Summary) adalah suatu prosedur yang dapat digunakan untuk mengidentifikasi Black Spot. Grafik Cusum merupakan suatu prosedur statistik standar sebagai kontrol kualitas untuk mendeteksi perubahan dari nilai mean.

Nilai Cusum dapat dicari dengan rumus [2]:

Mencari Nilai Mean (W)

Perhitungan untuk mencari nilai mean dari data sekunder, yaitu sebagai berikut:

$$
\mathrm{W}=\frac{\Sigma \mathrm{Xi}}{\mathrm{L} \times \mathrm{T}}
$$

Dimana:

$\mathrm{W}=$ Nilai mean

$\sum \mathrm{Xi}=$ Jumlah kecelakaan

$\mathrm{L}=$ Jumlah STA

$\mathrm{T}=$ Waktu/periode

Mencari Nilai Cusum Kecelakaan Tahun Pertama (so)

Perhitungan untuk mencari nilai Cusum kecelakaan tahun pertama adalah dengan mengurangi jumlah kecelakaan tiap tahun dengan nilai mean, yaitu:

Dimana:

$$
\mathrm{S}=(\mathrm{X} 1-\mathrm{W})
$$

\section{Mencari Nilai Cusum Kecelakaan Tahun Selanjutnya (Si)}

Untuk mencari nilai Cusum kecelakaan tahun selanjutnya adalah dengan menjumlahkan nilai Cusum tahun pertama dengan hasil pengurangan jumlah kecelakaan dan nilai mean pada tahun selanjutnya, yaitu:

Dimana:

$$
S=\left[S_{0}+(X 1-W)\right]
$$

$\mathrm{S}$ = Nilai Cusum kecelakaan

So = Nilai Cusum kecelakaan tahun pertama

$\mathrm{X}=$ Jumlah kecelakaan

4) Metode One Way - ANOVA

Analisis varians tunggal adalah sebuah metode dari ilmu statistik yang digunakan untuk menguji hipotesis apakah beberapa varietas yang diuji memberikan hasil yang sama identik atau berbeda nyata. Pada penelitian ini, metode One Way - ANOVA akan digunakan untuk menguji hipotesis apakah waktu, lokasi kejadian, jenis kelamin pelaku dan jenis kendaraan yg terlibat kecelakaan memberikan hasil yang sama identik atau berbeda nyata terhadap kecelakaan lalu lintas yang terjadi.

Dasar pengambilan keputusan uji ANOVA dari penelitian yang dilakukan adalah :

Perbandingan $F$ hitung dengan $F$ Tabel

Bila $\mathrm{F}$ hitung < F Tabel, maka Ho ditolak

Bila F hitung > F Tabel, maka Ho diterima, relatif identik Nilai Probabilitas

Bila $\mathrm{P}$ value $<0,05$ maka Ho ditolak

Bila $\mathrm{P}$ value $>0,05$ maka Ho diterima

\section{5) Metode The Gross Output (Human Capital)}

Metode The Gross Output (Human Capital) adalah sebuah metode untuk menghitung besaran biaya korban kecelakaan lalu lintas (biaya korban kecelakaan lalu lintas yang diakibatkan oleh suatu kejadian kecelakaan lalu lintas untuk setiap kelas kecelakaan lalu lintas). Biaya satuan korban kecelakaan lalu lintas adalah biaya yang diperlukan untuk perawatan korban kecelakaan lalu lintas untuk setiapkategori korban.

Perumusan The Gross Output (Human Capital) disajikan dalam persamaan berikut :

$$
B S K O i(T n)=B S K O\left(T_{0}\right) \times(1+g)^{t}
$$

Keterangan :

BSKOj $(\mathrm{Tn})=$ biaya satuan korban kecelakaan lalu lintas pada tahun $\mathrm{N}$ untuk setiap kelas kecelakaan (rupiah/korban)

BSKOj $(\mathrm{To})=$ biaya satuan korban kecelakaan lalu lintas pada tahun 2003 untuk setiap kelas kecelakaan (rupiah/korban)

$\mathrm{g}=$ tingkat inflasi biaya satuan kecelakaan (\%), nilai standart $\mathrm{g}=11 \%$

Tn = tahun perhitungan biaya korban

To $\quad=$ tahun dasar perhitungan biaya korban (2003)

$\mathrm{t}=$ selisih tahun perhitungan $(\mathrm{Tn}-\mathrm{To})$

i $\quad=$ kategori korban

Besaran biaya satuan kecelakaan lalu lintas dapat dilihat pada Tabel 1.

Tabel 1.

Besaran Biaya Satuan Korban Kecelakaan Lalu Lintas, BSKOj (To) [3] Klasifikasi Korban Korban Mati

Korban Luka Berat Biaya Satuan Korban

Korban Luka Ringan

$5.286 .000,00$

$1.045 .000,00$

So = Nilai Cusum kecelakaan tahun pertama

$\mathrm{Xi}=$ Jumlah kecelakaan tiap tahun

$\mathrm{W}=$ Nilai mean. 


\section{6) Angka Kecelakaan Lalu Lintas}

Untuk berbagai tujuan umum laju kecelakaan dihitung berkaitan dengan populasi, jumlah kendaraan terdaftar dan jumlah perjalanan kendaraan. Penggolongan data seringkali diperlukan dengan membagi menjadi data dikota dan diluar kota. Bentuk laju kecelakaan lalu lintas yang paling berguna adalah yang berhubungan dengan jumlah perjalanan kendaraan yang terkait dengan volume lalu lintas dan panjang jalan pada periode tertentu dua indek yang digunakan secara internasional adalah: [4]

$$
\begin{aligned}
N & =\frac{\text { jumlah kecelakaan luka-luka per tahun } \times 10^{\wedge} 6}{\text { panjang jalan }(\mathrm{km}) \times \text { arus lalu lintas per tahun }} \\
K & =\frac{\text { jumlah kematian per tahun } \times 10^{\wedge} 8}{\text { panjang jalan }(\mathrm{km}) \times \text { arus lalu lintas per tahun }}
\end{aligned}
$$

Dimana:

$\mathrm{N} \quad=$ Kecelakaan luka-luka per satu juta kilometer kendaraan per tahun

$\mathrm{K}=$ Kematian per 100 juta kilometer kendaraan per tahun

Perumusan ini dapat diterapkan untuk menghitung angka kecelakaan pada berbagai jenis jalan, asalkan diketahui jumlah total kecelakaan selama periode pengamatan, panjang jalan yang ditinjau, dan data lalu lintas kendaraan yang melewati jalan tersebut. Dimana dari ruas jalan tersebut akan diperoleh hasil berupa seberapa besar pengaruh antara angka kecelakaan lalu lintas dengan tipe jalan [5].

\section{METODOLOGI}

Diagram Alir Penelitian pengerjaan untuk menyelesaikan penelitian tersebut pada Gambar 1 berikut:

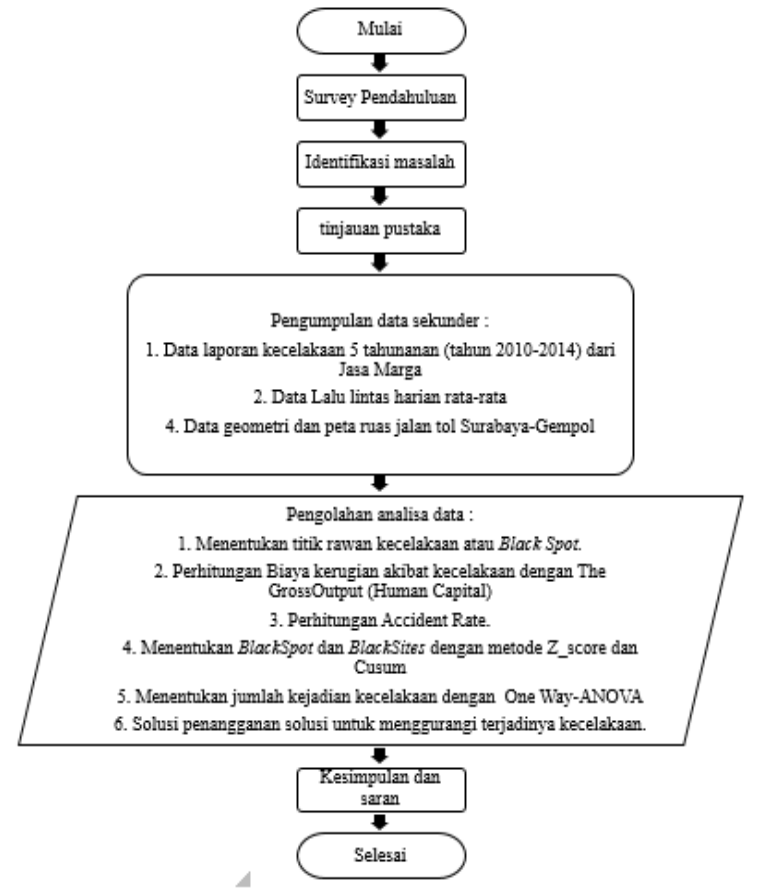

Gambar 1. Diagram alir metodologi penyelesaian.

\section{ANALISIS DAN PEMBAHASAN}

A. Analisis Data Karakteristik Kejadian Kecelakaan Lalu Lintas.

Analisis kejadian kecelakaan lalu lintas yang dimaksud adalah analisis terjadinya kecelakaan lalu lintas terhadap beberapa parameter yang memiliki hubungan dengan kejadian kecelakaan lalu lintas tersebut.
1) Analisis kejadian kecelakaan lalu lintas berdasarkan waktu (bulan)

Kecelakaan lalu lintas di sepanjang jalan tol SurabayaGempol jika dilihat dari prosentase kejadiannya, terjadi merata di setiap bulannya.

\section{Kejadian Kecelakaan berdasarakn Bulan}

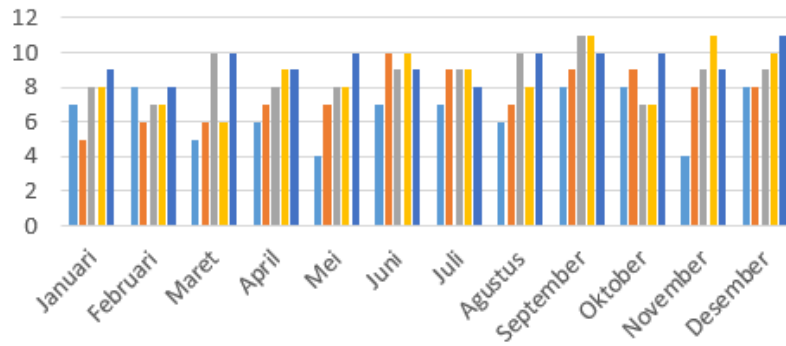

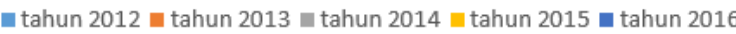

Gambar. 2. Grafik jumlah kejadian kecelakaan lalu-lintas berdasarkan bulan terjadinya.

2) Analisis kejadian kecelakaan lalu lintas berdasarkan waktu (hari)

Grafik kecelakaan lalu lintas terhadap waktu (hari)$$
25
$$

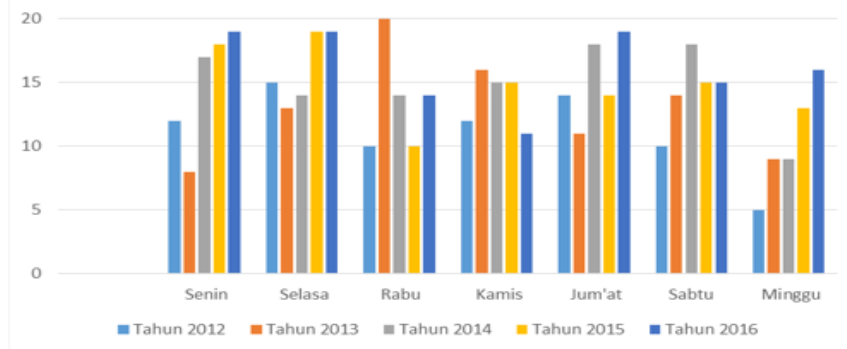

Gambar. 3. Grafik jumlah kejadian kecelakaan lalu-lintas berdasarkan hari terjadinya.

3) Analisis kejadian kecelakaan lalu lintas berdasarkan waktu (jam)

Grafik Kecelakaanlalu lintas terhadap waktu (jam)

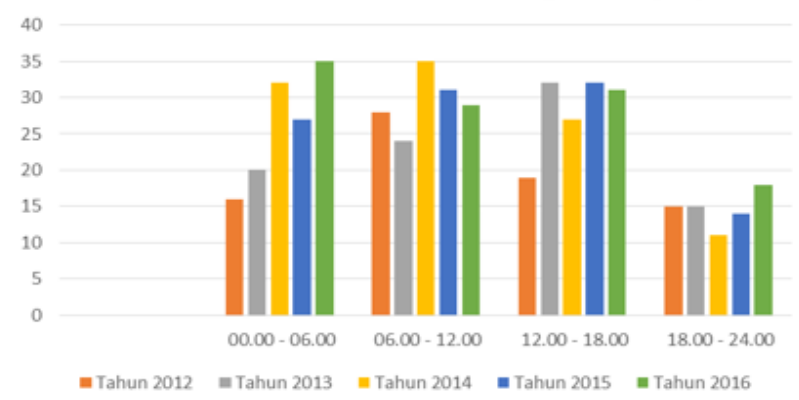

Gambar. 3. Grafik jumlah kejadian kecelakaan lalu-lintas berdasarkan waktu (jam) terjadinya.

4) Analisis kejadian kecelakaan lalu lintas berdasarkan jenis kelamin pelaku

Grafik Kecelakaan lalu lintas berdasarkan jenis pelaku

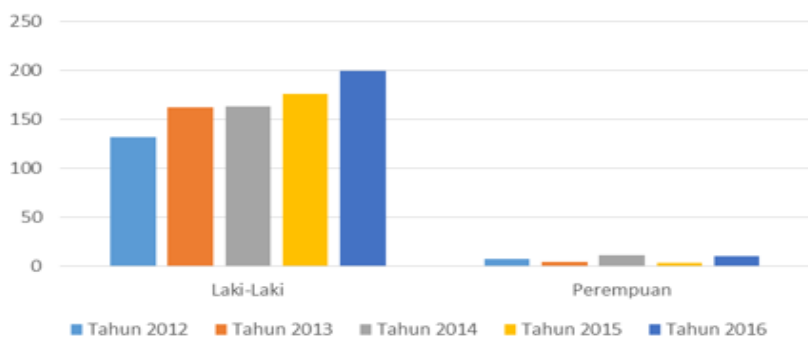

Gambar. 4. Grafik jumlah kejadian kecelakaan lalu-lintas berdasarkan jenis kelamin pelaku. 
5) Analisis kejadian kecelakaan lalu lintas berdasarkan cuaca

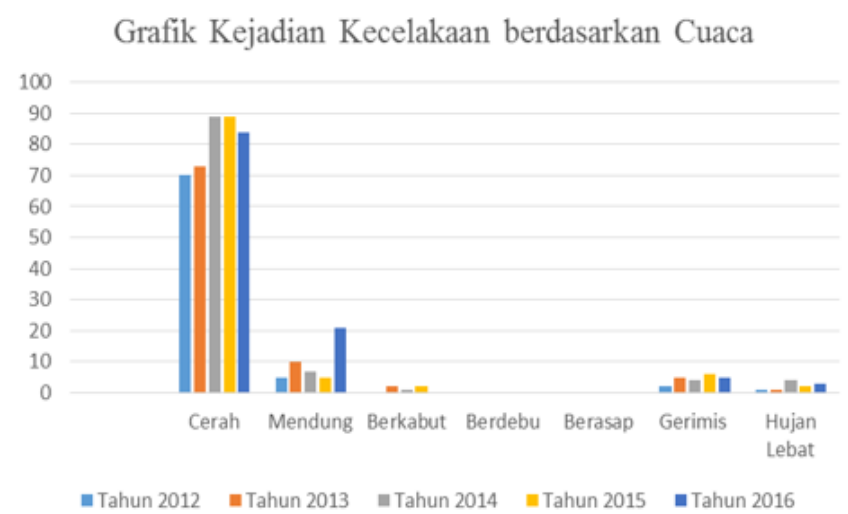

Gambar. 4. Grafik jumlah kejadian kecelakaan lalu-lintas berdasarkan cuaca.

\section{B. Uji Hipotesis dengan metode one way-ANNOVA}

Uji One Way - ANOVA antara jumlah kecelakaan dihubungkan dengan Bulan,Hari, Jam, Jenis Kelamin, Cuaca saat terjadinya kecelakaan. Hasil uji statistik dengan One Way - ANOVA melalui Minitab 16 antara kecelakaan lalu lintas pada ruas jalan tol Surabaya-Gempol selama 2012 2016 dengan beberapa faktor berpengaruh adalah :

1). Waktu

a) Bulan = Sama identik

b) Hari = Sama identik

c) Jam = Berbeda nyata

2). Cuaca = Berbeda nyata

3). Jenis Kelamin Pelaku = Berbeda nyata

\section{Analisis angka kecelakaan lalu lintas (Accident Rate)}

Untuk Menghitung besaran angka kecelakaan, diperlukan 3 data utama yang diperlukan untuk bisa menghitung besaran angka kecelakaan lalu lintas. Data-data yang dimaksud antara lain: data jumlah korban kecelakaan pada suatu ruas jalan tol, data panjang ruas jalan tol, dan data LHR lalu lintas.

Per 100 juta Kilometer Kendaraan Per Tahun untuk korban meninggal dunia.

Accident Rate $=\frac{\text { Jumlah Koran Meninggal Dunia X 10^8 }}{\text { Panjang Jalan } X \text { LHR X } 365}(11)$

Per 1 juta Kilometer Kendaraan Per Tahun untuk korban meninggal dunia, luka berar, dan luka ringan.

$$
\begin{aligned}
& \text { Accident Rate }= \frac{\text { Jumlah Koran Luka Berat } X 10^{6}}{\text { Panjang Jalan } X \text { LHR X 365 }} \\
& \text { Tabel } 2 .
\end{aligned}
$$

\begin{tabular}{|c|c|c|c|c|c|}
\hline No. & Nama Ruas & $\begin{array}{c}\text { Panjang } \\
(\mathrm{Km})\end{array}$ & $\begin{array}{c}\text { Jumlah } \\
\text { Korban } \\
\text { LB }\end{array}$ & LHR & $\begin{array}{l}\text { Angka Kecelakaan } \\
\text { Korban LB per } 1 \text { Juta } \\
\text { Km Kendaraan }\end{array}$ \\
\hline 1 & Perak-Perak & 4 & 2 & 18870 & 0.073 \\
\hline 2 & $\begin{array}{l}\text { Dupak-Banyu } \\
\text { Urip }\end{array}$ & 1.6 & 1 & 40492 & 0.042 \\
\hline 3 & $\begin{array}{l}\text { Banyu Urip- } \\
\text { Kota Satelit }\end{array}$ & 3.6 & 2 & 41196 & 0.037 \\
\hline 4 & $\begin{array}{l}\text { Kota Satelit- } \\
\text { Gungun Sari }\end{array}$ & 2.8 & 2 & 46547 & 0.042 \\
\hline 5 & $\begin{array}{l}\text { Gungung Sari- } \\
\text { Waru }\end{array}$ & 5 & 4 & 44274 & 0.05 \\
\hline 6 & Waru-Sidoarjo & 11 & 11 & 28636 & 0.096 \\
\hline 7 & $\begin{array}{l}\text { Sidoarjo- } \\
\text { Porong }\end{array}$ & 9 & 5 & 20979 & 0.073 \\
\hline 8 & $\begin{array}{l}\text { Porong- } \\
\text { Gempol }\end{array}$ & 3.8 & 0 & 0 & \\
\hline
\end{tabular}

Angka Kecelakaan Korban LB per 1 juta Km Kendaraan
Tabel 3.

\begin{tabular}{|c|c|c|c|c|c|}
\hline No. & Nama Ruas & $\begin{array}{c}\text { Panjang } \\
(\mathrm{Km})\end{array}$ & $\begin{array}{l}\text { Jumlah } \\
\text { Korban } \\
\text { Lr }\end{array}$ & LHR & $\begin{array}{c}\text { Angka Kecelakaan } \\
\text { Korban LR per } 1 \\
\text { Juta Km } \\
\text { Kendaraan }\end{array}$ \\
\hline 1 & Perak-Perak & 4 & 5 & 18870 & 0.181 \\
\hline 2 & $\begin{array}{c}\text { Dupak-Banyu } \\
\text { Urip }\end{array}$ & 1.6 & 6 & 40492 & 0.254 \\
\hline 3 & $\begin{array}{l}\text { Banyu Urip- } \\
\text { Kota Satelit }\end{array}$ & 3.6 & 9 & 41196 & 0.166 \\
\hline 4 & $\begin{array}{l}\text { Kota Satelit- } \\
\text { Gungun Sari }\end{array}$ & 2.8 & 12 & 46547 & 0.252 \\
\hline 5 & $\begin{array}{l}\text { Gungung } \\
\text { Sari-Waru }\end{array}$ & 5 & 16 & 44274 & 0.198 \\
\hline 6 & $\begin{array}{l}\text { Waru- } \\
\text { Sidoarjo }\end{array}$ & 11 & 23 & 28636 & 0.2 \\
\hline 7 & $\begin{array}{l}\text { Sidoarjo- } \\
\text { Porong }\end{array}$ & 9 & 12 & 20979 & 0.174 \\
\hline 8 & $\begin{array}{l}\text { Porong- } \\
\text { Gempol }\end{array}$ & 3.8 & 0 & 0 & \\
\hline
\end{tabular}

Angka Kecelakaan Korban LR per 1 juta Km Kendaraan

Tabel 4.

\begin{tabular}{|c|c|c|c|c|c|}
\hline No. & Nama Ruas & $\begin{array}{c}\text { Jumlah } \\
\text { Korban } \\
\text { MD }\end{array}$ & LHR & $\begin{array}{c}\text { Angka } \\
\text { Kecelakaan } \\
\text { Korban MD } \\
\text { per } 100 \text { Juta } \\
\text { Km } \\
\text { Kendaraan }\end{array}$ & $\begin{array}{c}\text { Angka } \\
\text { Kecelakaan } \\
\text { MD per } 1 \\
\text { juta Km } \\
\text { Kendaraan }\end{array}$ \\
\hline 1 & $\begin{array}{l}\text { Perak- } \\
\text { Perak }\end{array}$ & 1 & 18870 & 3.63 & 0.036 \\
\hline 2 & $\begin{array}{c}\text { Dupak- } \\
\text { Banyu Urip } \\
\text { Banyu }\end{array}$ & 0 & 40492 & 0 & 0 \\
\hline 3 & $\begin{array}{l}\text { Urip-Kota } \\
\text { Satelit } \\
\text { Kota }\end{array}$ & 0 & 41196 & 0 & 0 \\
\hline 4 & $\begin{array}{l}\text { Satelit- } \\
\text { Gungun } \\
\text { Sari }\end{array}$ & 1 & 46547 & 2.102 & 0.021 \\
\hline 5 & $\begin{array}{l}\text { Gungung } \\
\text { Sari-Waru }\end{array}$ & 0 & 44274 & 0 & 0 \\
\hline 6 & $\begin{array}{l}\text { Waru- } \\
\text { Sidoarjo }\end{array}$ & 5 & 28636 & 4.349 & 0.043 \\
\hline 7 & $\begin{array}{l}\text { Sidoarjo- } \\
\text { Porong }\end{array}$ & 3 & 20979 & 4.353 & 0.044 \\
\hline 8 & $\begin{array}{l}\text { Porong- } \\
\text { Gempol }\end{array}$ & 0 & 0 & 0 & \\
\hline
\end{tabular}

Angka Kecelakaan Korban MD per 1 juta Km Kendaraan

D. Perhitungan Besaran Biaya Korban Kecelakaan Lalu Lintas dengan Metode The Gross Output (Human Capital)

Menghitung estimasi biaya satuan korban kecelakaan pada tahun 2014 dilakukan dengan rumus:

$$
\operatorname{BSKO}\left(T_{2012}\right)=B S K O\left(T_{0}\right) \times(1+g)^{t}
$$

Dimana BSKO (To) adalah biaya satuan korban kecelakaan lalu lintas untuk setiap kategori korban, dalam satuan rupiah/korban, 'g' adalah tingkat inflasi biaya satuan korban kecelakaan lalu lintas, dalam satuan \% dimana nilai ' $\mathrm{g}$ ' yang digunakan penulis adalah nilai default g yaitu sebesar $11 \%$. Untuk perhitungan estimasi biaya satuan korban kecelakaan lalu lintas adalah sebagai berikut:

a) Korban meninggal dunia

$\operatorname{BSKO}\left(\mathrm{T}_{2012}\right)=119.016 .000 \times(1+11 \%)^{9}$

$\operatorname{BSKO}\left(\mathrm{T}_{2012}\right)=\operatorname{Rp} 304.447 .322-$

b) Korban luka berat

BSKO $\left(\mathrm{T}_{2012}\right)=5.826 .000 \times(1+11 \%)^{9}$

$\operatorname{BSKO}\left(\mathrm{T}_{2012}\right)=\operatorname{Rp} 14.903 .123-$

c) Korban luka ringan

$\operatorname{BSKO}\left(\mathrm{T}_{2012}\right)=1.045 .000 \times(1+11 \%)^{9}$

$\operatorname{BSKO}\left(\mathrm{T}_{2012}\right)=\operatorname{Rp} 2.673 .148$ 
Tabel 5.

Jumlah Korban Kecelakaan Lalu Lintas Ruas Jalan tol SurabayaGempol Tahun 2012

\begin{tabular}{ccccc}
\hline \hline \multirow{2}{*}{ No. } & \multirow{2}{*}{ Nama Ruas } & \multicolumn{3}{c}{ Jumlah Korban } \\
\cline { 3 - 5 } & & MD & LB & LR \\
\hline 1 & Perak-Perak & 1 & 2 & 5 \\
2 & Dupak-Banyu Urip & 0 & 1 & 6 \\
3 & Banyu Urip-Kota Satelit & 0 & 2 & 9 \\
4 & Kota Satelit-Gungun & 1 & 2 & 12 \\
5 & Sari & 0 & 4 & 16 \\
6 & Gungung Sari-Waru & 5 & 11 & 23 \\
7 & Waru-Sidoarjo & 3 & 5 & 12 \\
8 & Sidoarjo-Porong & 0 & 0 & 0 \\
\hline \hline
\end{tabular}

Tabel 6.

Besaran Biaya Korban Kecelakaan Lalu Lintas

\begin{tabular}{ccccc}
\multicolumn{5}{c}{ Besaran Biaya Korban Kecelakaan Lalu Lintas } \\
\cline { 2 - 4 } No. & MD & LB & LR & \multirow{2}{*}{ Total } \\
\cline { 2 - 4 } & Rp304,447,323 & Rp29,806,246 & Rp13,365,743 & Rp347,619,312 \\
2 & - & Rp14,903,123 & Rp16,038,892 & Rp30,942,01Bad \\
3 & - & Rp29,806,246 & Rp24,058,337 & Rp53,864,58meng \\
4 & Rp304,447,323 & Rp29,806,246 & Rp32,077,783 & Rp366,331,3571a \\
5 & - & Rp59,612,492 & Rp42,770,377 & Rp102,382,870 \\
6 & Rp1,522,236,613 & Rp163,934,354 & Rp61,482,417 & Rp1,747,653,385 \\
7 & Rp913,341,968 & Rp74,515,616 & Rp32,077,783 & Rp1,019,935,386 \\
8 & - & - & - & - \\
\hline \hline
\end{tabular}

\section{E. Analisis lokasi Black Site}

Dalam menentukan Black Site dalam tugas akhir ini, penulis menggunakan metode Z-Score, Z-Score atau bilangan $\mathrm{Z}$ adalah bilangan standar atau bilangan baku, ZScore digunakan digunakan untuk membakukan angka kecelakaan pada tiap-tiap ruas jalan agar dapat dibandingkan dengan ruas jalan lainnya.

1) Mencari Nilai rata-rata angka kecelakaan (X_)

Nilai rata-rata $(X)$ adalah jumlah rata-rata angka kecelakaan dibagi dengan jumlah data.

2) Mencari Standar Deviasi

Nilai standar deviasi (S) adalah akar dari jumlah kuadrat rata-rata angka kecelakaan pertahun dikurangi rata-rata angka kecelakaan dibagi jumlah data.

\section{3) Mencari nilai $Z$}

Nilai Z-score (Z) adalah rata-rata angka kecelakaan pertahun dikurangi rata-rata angka kecelakaan dibagi standar deviasi.

Tabel 7.

Nilai Z-Score, Rata-rata Angka Kecelakaan per Tahun

\begin{tabular}{|c|c|c|c|c|c|c|c|}
\hline $\begin{array}{l}\text { Ruas } \\
\text { Jalan }\end{array}$ & $\mathrm{N}$ & $X$ & $X^{\prime}$ & $X-' X$ & $\left(\mathrm{X}-{ }^{\prime} \mathrm{X}\right)^{2}$ & $\mathrm{~S}$ & $\mathrm{Z}$ \\
\hline $\begin{array}{l}\text { Perak- } \\
\text { Perak }\end{array}$ & 1119 & 139.9 & 196.23 & -56 & 3176.379 & 136.5 & -0.41 \\
\hline $\begin{array}{l}\text { Dupak- } \\
\text { Banyu } \\
\text { Urip }\end{array}$ & 646 & 80.75 & 196.23 & -115 & 13336.64 & 136.5 & -0.085 \\
\hline $\begin{array}{l}\text { Banyu } \\
\text { Urip- } \\
\text { Kota } \\
\text { Satelit }\end{array}$ & 1086 & 135.8 & 196.23 & -60 & 3658.36 & 136.5 & -0.44 \\
\hline $\begin{array}{l}\text { Kota } \\
\text { Satelit- } \\
\text { Gungun } \\
\text { Sari }\end{array}$ & 1334 & 166.8 & 196.23 & -29 & 869.328 & 136.5 & -0.22 \\
\hline $\begin{array}{l}\text { Gungung } \\
\text { Sari- } \\
\text { Waru }\end{array}$ & 2054 & 256.8 & 196.23 & 61 & 3662.141 & 136.5 & 0.44 \\
\hline $\begin{array}{l}\text { Waru- } \\
\text { Sidoarjo }\end{array}$ & 4096 & 512 & 196.23 & 316 & 99707.93 & 136.5 & 2.31 \\
\hline $\begin{array}{l}\text { Sidoarjo- } \\
\text { Porong }\end{array}$ & 1872 & 234 & 196.23 & 38 & 1426.242 & 136.5 & 0.28 \\
\hline $\begin{array}{l}\text { Porong- } \\
\text { Gempol }\end{array}$ & 352 & 44 & 196.23 & -152 & 23175.31 & 136.5 & -1.12 \\
\hline
\end{tabular}

\section{F. Analisis Titik Rawan Kecelakaan Black Spot}

Titik rawan kecelakaan lalu lintas atau Black Spot merupakan titik pada ruas jalan yang rawan terjadi kecelakaan lalu lintas. Metode yang penulis gunakan untuk menentukan titik rawan kecelakaan pada Tugas Akhir ini adalah metode Cummulative Summary atau (Cusum).

4) Nilai rata-rata

Nilai rata-rata mean (W) adalah jumlah kecelakaan lalu lintas selama 5 tahun, dibagi dengan jumlah stationing (L) dikali waktu/periode $(\mathrm{T})$, sehingga:

$$
W=\frac{\Sigma X_{i}}{L \times T}
$$

Tencari nilai Cusum kecelakaan lalu lintas tahun pertama $(S)$

Untuk mendapatkan nilai Cusum kecelakaan lalu-lintas da tahun pertama yaitu pada tahun 2012 adalah dengan rata-rata:

$$
S_{0}=\left(X_{i}-W\right)
$$

Mencari nilai cusum kecelakaan lalu lintas pada tahun berikutnya

$$
\begin{gathered}
S=S_{0}+\left(X_{i}-W\right) \\
\text { Tabel } 9 .
\end{gathered}
$$

\begin{tabular}{|c|c|c|c|c|c|c|c|}
\hline No. & STA & Tahun & $\begin{array}{l}\text { Jumlah } \\
\text { Kecelakaan } \\
\text { (Xi) }\end{array}$ & $\begin{array}{c}\Sigma \\
\mathrm{Xi}\end{array}$ & W & $(\mathrm{Xi}-\mathrm{W})$ & $\mathrm{Si}$ \\
\hline \multirow{5}{*}{1} & \multirow{5}{*}{$0-1$} & 2012 & 0 & 491 & 2.23 & -2.23 & $4 . \overline{46}$ \\
\hline & & 2013 & 0 & 491 & 2.23 & -2.23 & $\overline{-}$ \\
\hline & & 2014 & 1 & 491 & 2.23 & -1.23 & 3.46 \\
\hline & & 2015 & 3 & 491 & 2.23 & 0.77 & $\overline{1.46}$ \\
\hline & & 2016 & 1 & 491 & 2.23 & -1.23 & $\begin{array}{c}- \\
3.46\end{array}$ \\
\hline
\end{tabular}

Contoh Tabel perhitungan Black Spot dengan metode Cusum untuk STA 0-1 tahun 2012-2016

\section{G. Solusi Kecelakaan}

1) Analisis Faktor Penyebab dan Alternatif Solusi untuk Meminimalkan Kecelakaan Lalu Lintas

Jika melihat jumlah kejadian kecelakaan lalu lintas yang terus meningkat dari tahun ke tahu, maka perlu dilakukan analisis faktor - faktor yang menyebabkan dan solusi untuk menimalisir kemungkinan terjadinya kecelakaan lalu lintas tersebut.

\section{2) Faktor-faktor Penyebab Kecelakaan Lalu Lintas}

Faktor - faktor penyebab terjadinya kecelakaan lalu lintas perlu dicari untuk selanjutnya dapat ditentukan solusi yang tepat guna dapat meminimalkan kemungkinan terjadinya kecelakaan lalu lintas. Secara umum, faktor - faktor yang menyebabkan terjadinya kecelakaan lalu lintas ada 3 faktor, yaitu :

\section{a) Faktor manusia}

Faktor manusia atau yang lebih akrab disebut sebagai human error merupakan salah satu penyebab utama terjadinya kecelakaan lalu lintas di jalan raya. Mengabaikan peringatan untuk lebih waspada hingga melanggar peraturan lalu lintas menjadi sebuah kecenderungan yang dimiliki oleh para pengguna jalan raya, seperti pengemudi dalam keadaan lelah, mengantuk atau bahkan dalam pengaruh minuman keras atau narkotika, pengemudi lepas kendali/tidak mampu mengontrol laju kendaraanya 
b) Faktor kendaraan

Kendaraan menjadi satu hal yang penting saat membicarakan keselamatan berlalu lintas di jalan raya. Kendaraan yang digunakan oleh para pengemudi harus dalam kondisi baik dan layak dikendarai. Pemeliharaan dan pengontrolan kendaraan secara teratur dapat menunjang performa kendaraan sehingga layak digunakan.

c) Faktor kondisi geometri jalan

Kondisi jalan yang buruk merupakan penyebab lain terjadinya kecelakaan, seperti permukaan aspal bergelombang, retak hingga berlubang. Selain itu, pemisah jalan yang hanya berupa marka tanpa median jalan juga disinyalir menjadi penyebab seringnya terjadi kecelakaan di sepanjang Jalan tol Surabaya-Gempol karena sering pengguna jalan tol berhenti dan berbelok serta berpindah lajur di sembarang tempat. Kondisi penerangan jalan yang kurang baik menambah tingginya kemungkinan terjadinya kecelakaan karena jarak pandang pengguna jalan raya terbatas.

3) Alternatif Solusi untuk Meminimalisir Kecelakaan Lalu Lintas.

Hal - hal yang harus dilakukan untuk meminimalisir terjadinya kecelakaan lalu lintas tidak hanya melalui perbaikan fisik, seperti perbaikan jalan, pembangunan sarana tambahan, pemasangan rambu - rambu peringatan, tetapi juga psikis para pengguna jalan agar jiwa - jiwa melanggar peraturan lalu lintas yang ada berkurang, bahkan hilang.

Rencana program penanganan dalam mereduksi kecelakaan lalu lintas pada jalan tol Surbaya-Gempol secara Single Sites dan Mass Action Penanganan secara mass action adalah penanganan yang umum terhadap lokasi-lokasi dengan faktor penyebab yang sudah umum. Rencana program-program yang dapat dilaksanakan dengan mereduksi kecelakaan.

\section{KESIMPULAN DAN SARAN}

\section{A. Kesimpulan}

1) Accident rate pada ruas jalan tol Surabaya-Gempol selama 2012 - 2016 berdasarkan:

a) Klasifikasi kecelakaan fatal atau meninggal dunia, yang tertinggi sebesar 32,83 kecelakaan/ 100JPKP dan yang terendah dengan 0 kecelakaan/ 100JPKP.

b) Klasifikasi kecelakaan luka berat, yang tertinggi dengan 0,146 kecelakaan/ $1 \mathrm{JPKP}$ dan yang terendah terjadi dengan 0 kecelakaan/ 1JPKP.

c) Klasifikasi kecelakaan luka ringan, yang tertinggi dengan 0,33 kecelakaan/ 1JPKP dan yang terendah terjadi dengan 0,074 kecelakaan/ 1JPKP.
2) Hubungan kecelakaan lalu lintas dengan beberapa faktor berpengaruh pada ruas jalan tol SurabayaGempol selama 2012 - 2016, yang paling dominan adalah :

a) Waktu

Bulan : September

Hari : Selasa dan Jumat

Jam : $06.01-12.00$

b) Jenis Kelamin Pelaku : Laki-laki

3) Hasil uji statistic dengan One Way - ANOVA melalui Minitab 16 antara kecelakaan lalu lintas pada ruas jalan tol Surabaya-Gempol selama 2012 - 2016 dengan beberapa faktor berpengaruh adalah:

a) Waktu

Bulan : Sama identik

Hari : Sama identik

Jam : Berbeda nyata

b) Cuaca : Berbeda nyata

c) Jenis Kelamin Pelaku : Berbeda nyata

4) Besaran biaya satuan kecelakaan lalu lintas ( BSKO Tn) dengan metode perhitungan The Gross Output (Human Capital) akibat kecelakaan lalu lintas secara total (kelas fatal dan ringan) yang terjadi pada ruas jalan tol Surabaya-Gempol selama 2012 - 2016 adalah :

a) $2012: \operatorname{Rp~3,668,728,882.84~}$

b) $2013 \quad:$ Rp $1,025,817,495.58$

c) $2014: \operatorname{Rp} 3,541,314,496,14$

d) 2015 : Rp. 3,674,303,714.64

e) 2016 : Rp. 7,070,750,302.38

5) Lokasi rawan kecelakaan lalu lintas tertinggi pada STA 18-19 dan STA 22-23

6) Alternatif solusi untuk mereduksi kecelakaan adalah dengan metode Single Site dan Mass Action.

\section{B. Saran}

Pada penelitian selanjutnya, dapat dilakukan analisis kecelakaan lalu lintas dihubungkan dengan kecepatan kendaraan, kondisi geometri jalan.

\section{DAFTAR PUSTAKA}

[1] M. I. Hasan, Pokok-Pokok Materi Statistik. Jakarta: Bumi Aksara, 2001.

[2] Austroads, Austroads Guide to Road design Part 4: Intersections and Crossings - General. 1968.

[3] K. Dan and B. Pd, "Perhitungan Besaran Biaya Kecelakaan Lalu Lintas dengan Menggunakan Metoda The Gross Output (Human Capital)."

[4] F. D. (Frederick D. Hobbs, Perencanaan dan Teknik Lalu Lintas. 1995.

[5] H. Oblesby, C, Teknik Jalan Raya. 1982. 